\title{
ANALSIS RISIKO KESEHATAN AKIBAT PAPARAN KARBON MONOKSIDA PADA HARI KERJA DAN CAR FREE DAY DI KAWASAN JALAN RAYA PUPUTAN NITI MANDALA RENON DENPASAR TAHUN 2016
}

\author{
Fransisca Helen Yuniar Malau*, Made Ayu Hitapretiwi \\ Program Studi Kesehatan Masyarakat Faultas. Kedokteran Universitas Udayana \\ *email: fransiscahelen26@gmail.com
}

\begin{abstract}
ABSTRAK
Perubahan kualitas udara dapat diakibatkan oleh adanya sumber-sumber pencemaran, baik yang bersifat alami maupun karena kegiatan manusia. Salah satu kegiatan manusia yang menjadi sumber pencemaran udara adalah aktifitas manusia menggunakan kendaraan bermotor untuk transportasi. Hampir $60 \%$ dari polutan yang dihasilkan transportasi adalah gas karbon monoksida. Meningkatnya kadar emisi gas CO dalam udara dapat mempengaruhi kadar karbon monoksida pada udara ambien. Tujuan penelitian ini adalah untuk mengetahui risiko kesehatan akibat paparan CO pada populasi berisiko di Kawasan Jalan Raya Puputan Niti Mandala renon Denpasar. Rancangan penelitian ini merupakan penelitian desktriptif dengan metode ARKL. Sampel pada penelitian ini adalah konsentrasi CO pada hari kerja dan car free day, serta populasi berisiko (Juru Parkir, Satpam, Pedagang Kaki Lima, dan Polisi Lalu Lintas) di kawasan Jalan Raya Puputan Renon Denpasar. Penentuan sampel manusia menggunakan teknik purposif sampling dengan jumlah 60 responden, dengan kriteria bekerja di lokasi penelitian lebih dari setahun, usia pekerja, tidak merokok dan bersedia menjadi responden. Data dikumpulkan dengan metode observasi dan wawancara kemudian dianalisis dengan metode ARKL dan di olah menggunakan Microsoft Excel 2016 dan IBM SPSS Versi 18,00. Hasil penelitian ini menunjukkan konsentrasi CO rata-rata pada hari kerja di kawasan Jalan Raya Puputan Renon Denpasar sebesar 7,69 $\mu \mathrm{g} / \mathrm{m}^{3}$ dan pada saat Car Free Day sebesar $0,16 \mu \mathrm{g} / \mathrm{m}^{3}$. Semua konsentrasi CO masih di bawah nilai baku mutu. Nilai Intake (I) dan Risiko Questiens (RQ) tertinggi terhadap paparan CO terdapat pada hari kerja di kelompok Juru Parkir dengan mean Intake (I) sebesar

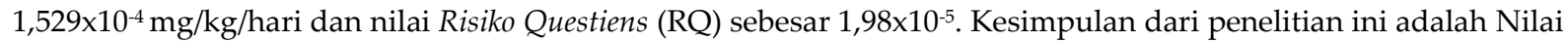
Intake (I) untuk risk agent CO di Kawasan Jalan Raya Puputan Niti Mandala Renon Denpasar tahun 2016 baik real time maupun life span pada hari kerja nilainya lebih tinggi dibandingkan pada saat Car Free Day.Nilai RQ hasil penelitian $\leq 1$, artinya paparan risk agent $C O$ belum menunjukkan risiko kesehatan nonkarsinogenik pada populasi berisiko.
\end{abstract}

Kata kunci : Analisis Risiko Kesehatan Lingkungan, Co, Hari Kerja, Car Free Day

\begin{abstract}
Changes in air quality can be caused by the presence of sources of pollution, both natural and due to human activities. One of the human activities that are sources of air pollution is human activities using motorized vehicles for transportation. Nearly $60 \%$ of the pollutants produced by transportation are carbon monoxide gas. Increased levels of CO gas emissions in the air can affect carbon monoxide levels in ambient air. The purpose of this study was to determine the health risks due to $\mathrm{CO}$ exposure in at-risk populations in the Puputan Niti Mandala Renon Denpasar Area. The design of this study is descriptive research with the ARKL method. The samples in this study were CO concentrations on weekdays and car free days, as well as risk populations (parking attendants, security guards, street vendors, and traffic police) in the Puputan Renon Denpasar area. Determination of the human sample using a purposive sampling technique with a total of 60 respondents, with the criteria of working at the study site for more than a year, age of workers, not smoking and willing to be respondents. Data were collected by observation and interview methods then analyzed by the ARKL method and processed using Microsoft Excel 2016 and IBM SPSS Version 18.00. The results of this study showed the average CO concentration on weekdays in the Puputan Renon Denpasar area was $7.69 \mu \mathrm{g} / \mathrm{m} 3$ and when the Car Free Day was $0.16 \mu \mathrm{g} / \mathrm{m} 3$. All CO concentrations are still below the quality standard. The highest Intake (I) value and Questiens (RQ) risk for CO exposure was found on working days in the Parking Attendant group with a mean Intake (I) of 1.529x10-4 mg / kg / day and a Questiens Risk (RQ) value of 1.98x10 -5. The conclusion of this study is the Intake (I) value for CO risk agents in the Puputan Niti Mandala Renon Denpasar Road Region in 2016 both real time and life span on working days are higher than during Car Free Day. RQ value of research results $\leq 1$ This means that exposure to $\mathrm{CO}$ risk agents has not demonstrated non-carcinogenic health risks in risk populations.
\end{abstract}

Keywords : Environtmental Health Risk Analysis, Co, Work Day, Car Free Day 


\section{PENDAHULUAN}

Udara terdiri dari campuran gasgas meliputi $78 \%$ Nitrogen; $20 \%$ Oksigen; 0,93 \% Argon; 0,03 \% Karbondioksida dan sisanya terdiri dari neon $(\mathrm{Ne})$, helium $(\mathrm{He})$, metan $(\mathrm{CH} 4)$ dan hidrogen (H2). Sebaliknya, apabila terjadi penambahan gas-gas lain yang menimbulkan gangguan serta perubahan komposisi tersebut, maka dikatakan udara sudah tercemar/terpolusi. Aktifitas manusia yang beraneka ragam dapat mengubah komposisi gas-gas dalam udara yang diikuti terjadinya perubahan kualitas udara.

Salah satu aktifitas manusia yang mengakibatkan pencemaran udara adalah penggunaan kendaraan bermotor. Emisi gas buang yang dihasilkan oleh setiap kendaraan menjadi sumber polusi utama dari seluruh penyebab pencemaran udara di perkotaan. Studi di beberapa kota besar antara lain Serang, Surakarta, Yogyakarta, Semarang, Surabaya termasuk Denpasar serta kotakota lain sepanjang pantai utara Pulau Jawa telah menunjukkan bahwa pencemaran udara yang terjadi sudah dan/atau hampir melampaui standar kualitas udara. Menurut Fardiaz (1992) sumber polusi utama berasal dari transportasi, hampir $60 \%$ dari polutan yang dihasilkan terdiri dari karbon monoksida.

Pengaruh CO terhadap tubuh terutama disebabkan oleh reaksi antara $\mathrm{CO}$ dengan hemoglobin $(\mathrm{Hb})$ dalam darah. Hemoglobin dalam darah secara normal berfungsi dalam sistem transpor untuk membawa oksigen dalam bentuk oksi hemoglobin $(\mathrm{O} 2 \mathrm{Hb})$ dari paru-paru ke sel-sel tubuh, dan membawa $\mathrm{CO}_{2}$ dalam bentuk $\mathrm{CO}_{2} \mathrm{Hb}$ dari sel-sel butuh ke paru-paru. Dengan adanya CO, hemoglobin dapat membentuk karboksihemoglobin (COHb). Hal ini menyebabkan kapasitas darah untuk menyalurkan oksigen ke jaringanjaringan tubuh menjadi terganggu atau berkurang.Keracunan gas karbon monoksida dapat mengakibatkan pusing, perubahan fungsi paru, detak jantung meningkat, kesukaran bernafas, kelainan fungsi susunan saraf pusat, gangguan pada sistem kardiovaskuler dan serangan jantung sampai pada kematian (Soemirat, 2005).

Dalam penelitian Decy Arwini (2014) kualitas udara pada kawasan Jalan Raya Puputan Renon Denpasar dalam evaluasi Indeks Standar Pencemaran Udara (ISPU) sesuai Keputusan Menteri Lingkungan Hidup No. 45 tahun 1997, kondisinya sudah termasuk kategori "sedang" dengan penjelasan bahwa tingkat kualitas udara tersebut tidak berpengaruh pada kesehatan manusia ataupun hewan tetapi berpengaruh pada tumbuhan sensitif dan nilai estetika (Kusminingrum, dan Gunawan, 2008).

Berdasarkan masalah diatas maka penelitian Analisis Risiko Kesehatan Lingkungan ini perlu dilakukan untuk menganalisis besarnya risiko kesehatan polusi udara akibat paparan gas karbon monoksida (CO) udara ambien yang berada di sekitar Jalan Raya Puputan Niti Mandala Renon Denpasar pada populasi berisiko seperti Juru Parkir, Satpam, Pedagang Kaki Lima dan Polisi Lalu Lintas. 


\section{METODE}

Penelitian ini menggunakan desain penelitian deskriptif dengan metode analisis risiko kesehatan lingkungan untuk menganalisis risiko kesehatan akibat paparan $\mathrm{CO}$ pada udara ambien. Dalam penelitian ini dilakukan pengumpulan data konsentrasi $\mathrm{CO}$ pada udara ambien dan data antropometri pada populasi berisiko terpapar CO. Populasi berisiko dalam penelitian ini terdiri dari kelompok Juru Parkir, Satpam, PKL dan Polantas. Jumlah sampel dalam penelitian ini sebanyak 60 orang.Kreteria inklusi dalam penelitian ini adalah laki-laki, bekerja $\leq 1$ tahun di lokasi penelitian, usia pekerja, dan tidak merokok.

Data yang digunakan dalam penelitian ini adalah jenis ada primer dan data sekunder. Data primer diproleh dengan cara metode wawancara menggunakan instrument kuisioner untuk variabel antropometri. Sedangkan untuk data sekunder diproleh dari hasil laboratorium pengukuran konsentrasi karbon monoksida pada udara ambien.

Data yang diperoleh di analisa secara statistic menggunakan metode Analisis Risiko Kesehatan Lingkungan (ARKL) yang meliputi 1) Identifikasi Bahaya (Hazard Identification), 2) Analisis Pemaparan (Exposure Assessment), 3) Analisis Dosis Respon (Dose Response Assessment), 4) Karakteristik Risiko (Risk Characterization). Data diolah menggunakan program Microsoft Excel 2016 dan IBM SPSS Versi 18,00.

\section{HASIL}

Konsentrasi Risk Agent CO pada hari kerja sebesar 7,69 $\mu \mathrm{g} / \mathrm{m}^{3}$ dan pada saat Car Free Day sebesar 0,16 $\mu \mathrm{g} / \mathrm{m}^{3}$.

Pada karakteristik responden sebagian besar responden berada pada kelompok umur 31-40 tahun yaitu sebanyak 29 orang (48,3\%), pekerjaan terbanyak sebagai Satpam sebanyak 20 orang $(33,3 \%)$, tingkat pendidikan responden terbanyak adalah SLTA sebanyak 43 orang(71,1\%), Indeks Massa Tubuh responden paling banyak berada dalam kategori normal yaitu sebanyak41 orang $(68,3 \%)$, dan tekanan darah responden paling banyak berada dalam kategori normal yaitu sebanyak 56 orang(93,3\%). Gangguan kesehatan yang dialami reponden paling banyak adalah gangguan penglihatan sebanyak 33 orang(55\%), dan perilaku responden yang paling tinggi adalah tidak menggunakan masker sebanyak 55 orang $(91,7 \%)$.

Nilai antropometri populasi sampel di kawasan Jalan Raya Puputan Niti Mandala Renon Denpasar tahun 2016 terdiri dari nilai Berat Badan, waktu pajanan, frekuensi pajanan dalam satu tahun dan durasi pajanan. Berdasarkan hasil survey yang dilakukan, terlihat bahwa adanya perbedaan nilai antropometri pada masing-masing kelompok responden. Nilai Berat Badan minimal terdapat pada kelompok Juru Parkir dan maksimum terdapat pada kelompok Polisi lalu Lintas. Nilai pajanan harian minimal terdapat pada kelompok Juru parkir dan Polisi Lalu lintas dan nilai maksimum terdapat pada kelompok Satpam. Nilai Durasi pajanan 
minimal terdapat pada kelompok Polisi Lalu Lintas dan maksimum terdapat pada kelompok Satpam. Sedangkan nilai Frekuensi Pajanan minimal terdapat pada kelompok Polisi Lalu Lintas dan maksimum terdapat pada kelompok Juru Parkir.

Analisis Pemajanan dan Perhitungan (I) real time baik pada hari kerja dan Car Free Day dapat dilihat pada tabel 1

Tabel 1. Nilai Intake pada populasi berisiko

\begin{tabular}{|c|c|c|c|c|c|c|}
\hline \multirow{6}{*}{ No } & \multirow{6}{*}{ Hari } & \multirow{6}{*}{$\begin{array}{l}\text { Real timel } \\
\text { Life Span }\end{array}$} & \multicolumn{4}{|c|}{ Intake (mg/kg/hari) } \\
\hline & & & Juru & Satpam & Pedagang & Polisi \\
\hline & & & Parkir & & Kaki & Lalu \\
\hline & & & & & Lima & Lintas \\
\hline & & & $\left(\times 10^{-4}\right)$ & $\left(x 10^{-4}\right)$ & & $\left(\times 10^{-4}\right)$ \\
\hline & & & & & $\left(\times 10^{-4}\right)$ & \\
\hline \multirow[t]{2}{*}{1} & Hari & Real time & 1,529 & 1,499 & 1,265 & 0,668 \\
\hline & Kerja & Life span & 8,335 & 8,601 & 8,656 & 4,654 \\
\hline \multirow[t]{3}{*}{2} & Car & Real time & 0,032 & 0,031 & 0,026 & 0,014 \\
\hline & Free & Life span & 0,173 & 0,179 & 0,179 & 0,097 \\
\hline & Day & & & & & \\
\hline
\end{tabular}

Nilai RfC Karbon monoksida ketetapan data Integrated Risk yang digunakan pada penelitian ini Informastion System dari US-EPA. adalah 7,667 mg/kg/hari berdasarkan

Tabel 2. Nilai Karakteristik Risiko (RQ) pada populasi berisiko

\begin{tabular}{|c|c|c|c|c|c|c|}
\hline & & & \multicolumn{4}{|c|}{ Karakteristik Risiko (RQ) } \\
\hline & & & Juru & Satpam & Pedagang & Polisi \\
\hline & & & Parkir & & Kaki Lima & Lalu \\
\hline No & Hari & $\begin{array}{l}\text { Real timel } \\
\text { Life Span }\end{array}$ & $\left(\times 10^{-5}\right)$ & $\left(\times 10^{-5}\right)$ & $\left(\times 10^{-5}\right)$ & $\begin{array}{l}\text { Lintas } \\
\left(\times 10^{-5}\right)\end{array}$ \\
\hline \multirow[t]{2}{*}{1} & Hari & Real time & 1,98 & 1,95 & 1,64 & 0,87 \\
\hline & Kerja & Life span & 10,84 & 11,18 & 11,25 & 6,05 \\
\hline \multirow[t]{3}{*}{2} & Car & Real time & 0,04 & 0,04 & 0,03 & 0,02 \\
\hline & Free & Life span & 0,22 & 0,23 & 0,23 & 0,12 \\
\hline & Day & & & & & \\
\hline
\end{tabular}

Perbedaan nilai Intake serta dengan waktu pelaksanaan Car Free Day Karakteristik Risiko pada Hari Kerja dan Car Free Day diuji dengan t-test untuk membandingkan rata-rata nilai pada kelompok populasi berisiko di Kawasan Jalan Raya Puputan Niti Karakteristik Risiko pada hari kerja Mandala Renon Denpasar. Hasil t-tes 
Arc. Com. Health Juni 2018

ISSN: 2527-3620

menunjukkan nilai p-value lebih kecil dari 0,05.

\section{PEMBAHASAN}

Konsentrasi Risk Agent

Data dari penelitian ini menunjukkan hasil konsentrasi Karbon monoksida pada hari kerja lebih tinggi daripada waktu pelaksanaan Car Free Day. Terjadi penurunan konsentrasi Karbon monoksida sebesar 48 kali pada waktu pelaksanaan Car Free Day dibandingkan dengan hari kerja. Hal ini disebabkan banyaknya aktivitas menggunakan kendaraan bermotor untuk berangkat bekerja, antar anak sekolah, dan kegiatan lain yang berada di kawasan Jalan Raya Puputan Niti Mandala Renon Depasar pada hari kerja dibandingkan hari Minggu. Konsentrasi Karbon monoksida yang diperoleh pada hari kerja maupun saat Car Free Day masih dibawah baku mutu sesuai Peraturan Gubernur Bali No. 8 tahun 2007 tentang Baku Mutu Lingkungan Hidup dan Kriteria Baku Kerusakan Lingkungan Hidup yang menyebutkan baku mutu konsentrasi Karbon monoksida dalam udara ambien sebesar $30,00 \mu \mathrm{g} / \mathrm{m}^{3}$.

Merujuk pada hasil penelitian Decy Arwini (2014), didapat hasil yang hampir sama pada hari kerja. Konsentrasi karbon monoksida pada hari kerja yang didapat pada penelitian Decy Arwini (2014) sebesar 7,46 $\mu \mathrm{g} / \mathrm{m} 3$ sedangkan pada penelitian ini sebesar 7,69 $\mu \mathrm{g} / \mathrm{m} 3$. Namun, hasil penelitian yang diperoleh saat Car Free Day sedikit berbeda. Pada penelitian Decy Arwini konsentrasi Karbon monoksida yang
Vol. 5 No. $1: 19$ - 26 diperoleh sebesar 1,60 $\mu \mathrm{g} / \mathrm{m} 3$ sedangkan pada penelitian ini konsentrasi Karbon monoksida yang didapat sebesar 0,16 $\mu \mathrm{g} / \mathrm{m} 3$. Walaupun demikian, hasil penelitian sama-sama menunjukkan konsentrasi Karbon monoksida pada waktu pelaksanaan Car Free Day lebih rendah dibandingkan pada hari kerja. Hasil penelitian ini membuktikan dampak pelaksanaan kegiatan Car Free Day sangat berpengaruh dalam menurunkan konsentrasi polutan di udara.

Karakteristik Antropometri meliputi berat badan, semakin besar berat badan individu semakin kecil dosis internal yang diterima (Rahman, 2006).Hasil penelitian menunjukkan berat badan minimal terdapat pada kelompok Juru Parkir dengan nilai mean sebesar 57,25 dan nilai standar deviasi sebesar 6,902. Nilai mean berat badan paling maksimal terdapat pada kelompok Polisi Lalu Lintas yang memiliki berat lebih dari rata-rata orang Asia yaitu sebesar 75,13 dengan nilai standar deviasi sebesar 3,998.

Berdasarkan hasil survey, nilai mean pajanan harian ( $\left.t_{E}\right)$ paling minimal terdapat pada kelompok Juru Parkir dan Polisi Lalu Lintas masing-masing sebesar 8,00 dengan nilai standar deviasi masing masing sebesar 0,000 . Nilai mean pajanan harian paling maksimum terdapat pada kelompok Satpam sebesar 12 dengan nilai standar deviasi sebesar 0,000, hal ini dikarenakan jadwal shift kerja mereka yang berkaitan dengan keamanan kantor selama 24 jam.

Nilai frekuensi pajanan $\left(\mathrm{f}_{\mathrm{E}}\right)$ didapat dari lama hari dalam satu tahun (365 
hari) dikurangi dengan jumlah libur kerja dalam setahun. Nilai mean pajanan tahunan paling minimum dari semua responden terdapat pada kelompok Polisi Lalu Lintas sebesar 249 dengan standar deviasi sebesar 0,000. Nilai pajanan tahunan maksimum dan mean/median tertinggi terdapat pada kelompok Juru Parkir sebesar 357 dengan standar deviasi sebesar 0,000, hal ini dikarenakan aktivitas harian sepanjang tahun yang dilakukan kelompok ini cukup tinggi di kawasan Jalan Raya Puputan Renon Denpasar.

Nilai Durasi Pajanan (Dt) yang terendah dan tertinggi terdapat pada kelompok Juru Parkir. Berdasarkan perhitungan asupan (Intake) diketahui bahwa waktu pajanan harian dan frekuensi pajanan tahunan berbanding lurus dengan nilai asupan (Intake) yang diterima orang tersebut. Semakin tinggi nilai asupan (Intake) yang diterima orang tersebut maka semakin tinggi risiko terhadap gangguan kesehatan pada orang tersebut akibat pajanan risk agen (Junaidi, 2007).

Analisis Pemajanan dan Perhitungan (I)

Bila dilihat dari kelompok hari maka nilai Intake tertinggi ada pada hari kerja dan terendah ada pada saat Car Free Day, hal ini dikarenakan konsentrasi Karbon monoksida pada hari kerja cukup tinggi jika dibandingkan saat Car Free Day.

Kemudian bila dilihat pada masing-masing kelompok responden, nilai asupan (Intake) juga berbeda-beda. Bila dilihat nilai Intake real time tertinggi pada hari kerja dan Car Free Day terdapat pada kelompok Juru Parkir. Hal ini disebabkan oleh lama pajanan harian $(\mathrm{t})$, frekuensi pajanan $\left(\mathrm{f}_{\mathrm{E}}\right)$ dan durasi pajanan (Dt) yang tinggi dan nilai pembandingnya yaitu berat badan $\left(\mathrm{W}_{\mathrm{b}}\right)$ yang kecil dibandingkan kelompok lainnya. Sedangkan pada nilai Intake untuk waktu 30 tahun kedepan (life span) yang tertinggi terdapat pada kelompok Pedagang Kaki Lima. Ini dikarenakan pajanan harian kelompok Pedagang kaki lima lebih tinggi dibandingkan kelompok Juru Parkir dan Polantas sedangkan nilai pembandingnya yaitu berat badan lebih kecil dibandingkan kelompok Polisi lalu Lintas dan Satpam.

perbandingan nilai Intake baik real time maupunlife span pada hari kerja dan Car Free Day untuk semua kelompok responden berisiko pada penelitian ini terdapat perbedaan secara signifikan. Hal ini terjadi karena nilai risk agent yang diperoleh pada hari kerja dan Car Free Day sangat berbeda secara signifikan.

Karakteristik Risiko (RQ)

Hasil penelitian menunjukkan tingkat risiko (RQ) real time tertinggi terdapat pada kelompok Juru Parkir dan $\mathrm{RQ}$ life span tertinggi terdapat pada kelompok Pedagang Kaki Lima. Nilai ini berbanding lurus dengan nilai Intake real time dan life span yang didapat dari hasil survey pada penelitian ini, karena nilai pembanding yang digunakan sama pada semua populasi yaitu nilai konsentrasi referensi $(R f C)$.

semua nilai $R Q$ terdapat perbedaan secara signifikan pada seluruh nilai $R Q$ real time pada hari kerja dan Car Free Day untuk semua kelompok responden 
Vol. 5 No. $1: 19$ - 26

berisiko pada penelitian ini. Begitu juga pada perbandingan nilai RQ life span pada hari kerja dan Car Free Day untuk semua kelompok responden berisiko pada penelitian ini terdapat perbedaan secara signifikan. Hal ini terjadi karena nilai konsentrasi karbon monoksida yang diperoleh pada hari kerja dan Car Free Day sangat berbeda secara signifikan.

Dari hasil Analisis menunjukkan bahwa nilai RQ real time dan life span baik Hari Kerja maupun Car Free Day pada semua responden berisiko pada penelitian ini nilainya tidak ada yang melebihi ambang batas risiko kesehatan atau $\mathrm{RQ} \leq 1$. Hal ini menunjukkan belum adanya risiko kesehatan akibat paparan risk agent karbon monoksida pada responden berisiko di Kawasan Jalan Raya Puputan Renon Denpasar.

\section{SIMPULAN}

Konsentrasi Karbon monoksida dalam udara ambien pada bulan April 2016 di Kawasan Jalan Raya Puputan Niti Mandala Renon Denpasar, pada Hari Kerja sebesar 7,69 $\mu \mathrm{g} / \mathrm{m} 3$ dan pada saat Car Free Day sebesar 0,16 $\mu \mathrm{g} / \mathrm{m} 3$. Konsentrasi ini masih di bawah nilai Baku Mutu Udara Ambien menurut Peraturan Gubernur Bali Nomor : 8 tahun 2007 tentang Baku Mutu Lingkungan Hidup dan Kriteria Baku Kerusakan Lingkungan Hidup yaitu sebesar $30 \mu \mathrm{g} / \mathrm{m} 3$.

Nilai antropometri populasi sampel di kawasan Jalan Raya Puputan Niti Mandala Renon Denpasar tahun 2016 terdiri dari nilai Berat Badan, waktu pajanan, frekuensi pajanan dalam satu tahun dan durasi pajanan. Berdasarkan hasil survey yang dilakukan, terlihat bahwa adanya perbedaan nilai antropometri pada masing-masing minimal terdapat pada kelompok Juru Parkir dan maksimum terdapat pada kelompok Polisi lalu Lintas. Nilai pajanan harian minimal terdapat pada kelompok Juru parkir dan Polisi Lalu lintas dan nilai maksimum terdapat pada kelompok Satpam. Nilai Durasi pajanan minimal terdapat pada kelompok Polisi Lalu Lintas dan maksimum terdapat pada kelompok Satpam. Sedangkan nilai Frekuensi Pajanan minimal terdapat pada kelompok Polisi Lalu Lintas dan maksimum terdapat pada kelompok Juru Parkir.

Nilai Intake (I) untuk risk agent Karbon monoksida di Kawasan Jalan Raya Puputan Niti Mandala Renon Denpasar tahun 2016 baik real time maupun life span pada hari kerja nilainya lebih tinggi dibandingkan pada saat Car Free Day. Kelompok Juru Parkir adalah kelompok yang memiliki nilai Intake (I) relatif paling tinggi dibandingkan kelompok responden lainnya.

Nilai Risk Questiens (RQ) untuk risk agent Karbon monoksida di Kawasan Jalan Raya Puputan Niti Mandala Renon Denpasar tahun 2016 baik real time maupun life span pada hari kerja nilainya lebih tinggi dibandingkan pada saat Car Free Day. Kelompok Juru Parkir adalah kelompok yang memiliki nilai Risk Questiens (RQ) relatif paling tinggi dibandingkan kelompok responden lainnya. Nilai RQ hasil penelitian $\leq 1$, artinya paparan risk agent $\mathrm{CO}$ belum kelompok responden. Nilai Berat Badan 
Fransisca Helen Yuniar Malau \& Made Ayu Hitapretiwi

menunjukkan risiko kesehatan nonkarsinogenik pada populasi berisiko.

\section{DAFTAR PUSTAKA}

Arwini, Ni Putu Decy. 2014. Analisis Dampak Pelaksanaan Car Free Day di Kota Denpasar (StudiKasus: Jalan Raya Puputan Niti Mandala Renon Denpasar). Denpasar : Universitas Udayana

A. Tresna Sastrawijaya, 2000. Pencemaran Lingkungan. Jakarta: Rineka Cipta, Cet II, h.176.

ATSDR. (2012). Toxicological Profile For Carbon Monoxide. U.S. Department Of Health And Human Services. Public Health Service. Agency for Toxic Substances and Disease Registry. 2296.

Badan Lingkungan Hidup Kota Denpasar, 2008. Status Lingkungan Hidup Kota Denpasar Tahun 2008.

Basri, Syahrul.dkk. 2014. "Analisis Risiko Kesehatan Lingkungan (Model Pengukuran Risiko Pencemaran Udara terhadap Kesehatan)". Jurnal Kesehatan, [online], vol 7, No.2, hal.427-442, dari http://download.portalgaruda.org/ [21 januari 2016]

Chandra,B. 2007. Pengantar Kesehatan Lingkungan. Jakarta : Buku Kedokteran EGC

Fardiaz, S. 1992. Polusi Udara dan Air. Yogyakarta: Kanisius (hal.89-142).

Fardiaz, S. 1992. Polusi Air danUdara. Yogyakarta, Kanisius. (hal 91-103).

Hasneni, 2004. Evaluasi Tingkat Pencemaran Udara Berdasarkan Konsentrasi Udar Ambien di Kota Bandung, Skripsi. Bogor :
Vol. 5 No. $1: 19$ - 26

Departemen Geofisika dan Meteorologi, Institut Pertanian Bogor.

Kementrian Kesehatan Direktorat Jenderal PP dan PL. 2012. Pedoman Analisis Risiko Kesehatan Lingkungan.

Kusminingrum, N., Gunawan, G. 2008. Polusi Udara Akibat Aktivitas Kendaraan Bermotor di Jalan Perkotaan Pulau Jawa dan Bali. Puslitbang Jalan dan Jembatan. Bandung.

Kolluru, R.V., Bartel\&Pitblado, R. 1996. Risk Assessment and Management Handbook : for Environmental, Health and Safety Professional, McGraw Hill, New York.

Louvar,J.F., and B.D. Louvar. 1998. Health and Environmental Risk Analysis : Fundamental with Applicatin. New jersey : Prentice Hall. 